\title{
Chorioamnionitis, Postnatal Factors and Proinflammatory Response in the Pathogenetic Sequence of Bronchopulmonary Dysplasia
}

\section{Christian P. Speer}

University Children's Hospital, Würzburg, Germany

\section{Key Words}

Preterm infants - Bronchopulmonary dysplasia . Respiratory distress syndrome $\cdot$ Pathogenesis · Inflammation

\begin{abstract}
Pulmonary inflammation has a central role in the multifactorial and complex pathogenesis of bronchopulmonary dysplasia. Pre- and postnatal factors such as chorioamnionitis, oxygen toxicity, mechanical ventilation and postnatal infections can induce and perpetuate an injurious and complex inflammatory response in the airways and lung tissue of very immature infants. This inflammatory process is characterized by the accumulation of inflammatory cells and an arsenal of proinflammatory mediators such as cytokines, toxic oxygen radicals, lipid mediators and potent proteases. An imbalance between pro- and anti-inflammatory factors favoring the proinflammatory process can be considered as a hallmark of lung injury. In addition, impaired mechanisms of tissue remodeling and repair together with a subnormal generation of growth factors could affect alveolarization and vascular development with lifelong consequences for the infants with bronchopulmonary dysplasia.
\end{abstract}

Copyright $\odot 2009$ S. Karger AG, Base

\section{KARGER}

Fax +4161306 1234 E-Mail karger@karger.ch www.karger.com
(C) 2009 S. Karger AG, Base

1661-7800/09/0954-0353\$26.00/0

Accessible online at:

www.karger.com/neo

\section{Introduction}

Very immature infants who initially have minimal or absent signs of respiratory distress syndrome (RDS) may subsequently develop oxygen dependency and ventilatory needs within the first 10 days of life and remain oxygen-dependent for weeks and months [1]. More than half of these very immature infants with so-called 'new' bronchopulmonary dysplasia (BPD) may have been exposed to chorioamnionitis and a considerable number of them are born with inflamed lungs and signs of fetal inflammatory response. In addition, various postnatal factors such as resuscitation, high airway concentrations of inspired oxygen, mechanical ventilation, pulmonary as well as systemic infections and persistent ductus arteriosus may perpetuate or even amplify an injurious inflammatory response in the airways and interstitium which may subsequently affect normal alveolarization and pulmonary vascular development. The etiology of BPD is certainly multifactorial and the multiple-hit theory offers a plausible concept which helps to explain the complex pathogenetic mechanisms involved in this chronic lung disease of very immature preterm infants $[2,3]$. This paper expands on previously published articles and summarizes, in a condensed form, the current pathogenetic concepts of the possible role of inflammation in the evolution of BPD [4-7]. 


\section{Pre- and Postnatal Factors Inducing Pulmonary Inflammation}

\section{Chorioamnionitis}

Epidemiological data suggest a strong association between chorioamnionitis, funisitis and the development of $\mathrm{BPD}$, and increased concentrations of proinflammatory cytokines in human amniotic fluid and fetal cord blood, indicating a systemic inflammatory response during chorioamnionitis, are independent risk factors of BPD $[1$, $5,7]$. A pronounced infiltration of inflammatory cells, an increased expression of cytokines and markers of endothelial activation as well as a large number of apoptotic airway cells have been observed in lung tissues of human fetuses with funisitis that have been exposed to chorioamnionitis [8-10]. In addition, the presence of proteomic biomarkers characteristic of inflammation in the amniotic fluid was associated with an increased fetal inflammatory response at birth [11]. In an animal model, maternal exposure to endotoxin resulted in a prolonged pulmonary inflammatory response, altered gene expression and delayed maturation of the lung [12]. Congenital infections, which induce pulmonary or systemic fetal inflammation, seem to be a more frequent event than previously realized [13].

\section{Infection}

Early-onset sepsis and systemic nosocomial infections have clearly been identified as individual risk factors for BPD $[1,5,7,14-17]$. Besides direct adverse effects of microorganisms, a variety of inflammatory cells and mediators may affect the integrity of endothelial and bronchoalveolar cells. In addition, hemodynamic changes in the vascular bed associated with persistent ductus arteriosus seem to play an essential role in the development of BPD [18]. Vasoactive prostaglandin mediators released during septicemia probably prevent ductal closure or induce reopening of the duct [19]. The potential role of Ureaplasma urealyticum $(\mathrm{Uu})$ in the evolution of $\mathrm{BPD}$ is still controversial. $\mathrm{Uu}$ is the microorganism most frequently isolated from the amniotic fluid in preterm births and a predominant pathogen detected in airway secretions immediately after birth $[15,20]$. In the Alabama preterm birth study, Uu and Mycoplasma hominis were detected in cord blood cultures of $23 \%$ of very immature preterm infants. These infants were more likely to have neonatal systemic inflammatory response syndrome and probably BPD [21]. Animal experiments strongly indicate that antenatal $\mathrm{Uu}$ infection contributes to a prolonged proinflammatory response, early fibrosis, an altered de- velopmental signaling and changes in morphology and lung function in the immature lung $[20,22]$. The presence of $\mathrm{Uu}$ in the respiratory tract of preterm infants, even without clinical or laboratory signs of infection, was correlated with elevated cellular and molecular markers of inflammation and has been associated with an increased risk of BPD [23-25]. The inherent responses of the maternal and fetal immune system to antenatal Uu infection are still not understood; however, they probably determine the pulmonary outcome of preterm infants with $\mathrm{Uu}$ colonization [20]. In addition, the role of fetal and neonatal innate immunity such as surfactant proteins SP-A, SP$\mathrm{D}$ and Toll-like receptors is far from clear [26].

\section{Mechanical Ventilation}

Many in vitro studies and animal experiments clearly show that any ventilatory trauma of the immature lung may be injurious to airways and lung tissue. An excessive tidal volume (volutrauma), rather than high inspiratory pressure (barotrauma), is the primary determinant of lung injury. Overdistension of the lungs or cyclic opening and closing of lung units causes disruption of structural elements and a release of proinflammatory mediators with subsequent leukocyte influx [1, 5, 7, 27-33]. The strongest inflammatory reaction was observed in those ventilatory strategies with high peak pressure and no positive end-expiratory pressure. If animals were pretreated with lipopolysaccharide (LPS), bronchoalveolar lavage fluid levels of proinflammatory cytokines were impressively increased even with a 'less injurious' ventilation strategy [34]. 'Priming' of the fetal lung by LPS is a considerable pathogenetic factor in the initiation of the inflammatory reaction, and basically every form of mechanical ventilation may act as a 'second strike' that can amplify or aggravate the inflammatory response [7].

\section{Hyperoxia and Hypoxia}

Very immature preterm infants with their reduced antioxidant defense system are at high risk of suffering from potential detrimental effects of hyperoxia and hyperoxemia $[35,36]$. In preterm and full-term animals, hyperoxia has clearly been shown to be a strong and independent inducer of various mediators involved in pulmonary inflammation [37, 38]. Recently, differential gene expression with DNA microarray analysis in premature rat lungs exposed to prolonged hyperoxia during the saccular stage has been studied. Oxidative stress affected a complex orchestra of genes involved in inflammation, extracellular matrix turnover, coagulation and other events, and the majority of proinflammatory genes were 
considerably upregulated [39]. These findings were associated with an increased influx of inflammatory cells, especially macrophages in pulmonary tissue. Moreover, hyperoxia resulted in progressive lung disease which strongly resembled BPD. Current knowledge about the role of hypoxia in pulmonary inflammation is limited. A recent animal study demonstrated that hypoxia had a substantial effect on LPS-induced pulmonary inflammation by increasing the magnitude of lung injury reflected by increased expression of inflammatory mediators, excessive neutrophil accumulation and increased vascular permeability [40]. The role of a genetic predisposition to BPD is currently under investigation but has not provided conclusive data to date [41-43].

\section{Cellular and Soluble Mediators of Pulmonary Inflammation, Mechanisms of Lung Injury and Repair}

\section{Inflammatory Cells}

Neutrophils and macrophages have an essential role in acute and chronic stages of pulmonary inflammation. Much higher and persisting numbers of inflammatory cells were detected in bronchoalveolar lavage fluid of preterm infants with BPD when compared with infants who recovered from RDS [44-48]. Immediately after initiation of mechanical ventilation, a neutrophil influx into the airways was observed in animals as well as in preterm infants, and this inflammatory reaction was associated with a decrease in the number of circulating neutrophils $[49,50]$, and it was shown to correlate with the extent of pulmonary edema formation and an increased risk of developing $\mathrm{BPD}[3,51,52]$. In addition, circulating neutrophils and monocytes became activated within $1-3 \mathrm{~h}$ after initiation of mechanical ventilation as reflected by $\mathrm{CD} 11 \mathrm{~b}$ expression [53]. Following their activation, alveolar and pulmonary tissue macrophages secrete numerous cytokines and proinflammatory mediators which orchestrate the inflammatory response, particularly neutrophil recruitment. In lung tissues of preterm infants who had died during the early stages of RDS, the interstitial density of CD68-positive macrophages and neutrophils was at least 10- to 15-fold higher than in stillborn infants of equivalent age [54]. Since apoptosis of inflammatory neutrophils and their timely removal by resident macrophages are critical to the resolution of inflammation, neonatal neutrophils which seem to have a prolonged survival may have the functional capacity to perpetuate inflammation [55].

Chorioamnionitis, Postnatal Factors and Proinflammatory Response

\section{Chemotactic Factors and Endothelial Interactions}

Airway secretions of infants with BPD contain high concentrations of well-defined chemotactic factors which are responsible for the recruitment of neutrophils: C5a, tumor necrosis factor- $\alpha$ (TNF- $\alpha$ ), interleukin (IL)-1, IL8, IL-16, lipoxygenase products, leukotriene $\mathrm{B}_{4}$, elastin fragments, metalloproteases, fibronectin and others $[1,5$, $7,44]$. IL-8 is involved in the initiation of cellular endothelial interactions and is probably the most important chemotactic factor in the lung. In addition, potent $\beta$-chemokines that induce chemotaxis of monocytes and macrophages are present in the airway secretions of infants with RDS and BPD. These include monocyte chemotactic protein, macrophage inflammatory protein and growthrelated protein $[1,5,7]$. Chemotactic activity and concentrations of numerous chemotactic and chemokinetic factors were considerably higher in infants with BPD when compared with babies who recovered from RDS and preceded the marked neutrophil influx in infants with BPD [44]. Application of a selective chemokine receptor antagonist clearly inhibited neutrophil influx into the rat lung, suppressed pulmonary inflammation and enhanced lung growth [56]. Similarly, inhibition of phosphodiesterase 4 decreased influx of monocytes and macrophages in the airways of preterm infants and positively affected the extent of lung injury $[57,58]$.

Neutrophils and monocytes leave the circulation via a one-way exit into the extra-alveolar space. The complex mechanisms of cellular attachment to endothelial cells are mediated through an interaction with adhesion molecules and their ligands. Various data indicate that recruitment of circulating neutrophils and monocytes into the airways and pulmonary tissue of preterm infants is well functioning $[7,59]$.

\section{Pro- and Anti-Inflammatory Cytokines}

The proinflammatory cytokines TNF- $\alpha$, IL-1, IL- 6 and IL- 8 are synthesized by various inflammatory and pulmonary cells upon stimulation by hyperoxia, microorganisms, endotoxin (LPS), other bacterial cell wall constituents and biophysical factors such as volutrauma and barotrauma [1]. They play a crucial role in the initiation and in the evolution of the inflammatory response [41]. IL-1 present in the airway secretions of ventilated preterm infants induces IL-8 expression of epithelial cells via a nuclear transcription factor (NF- $\kappa \mathrm{B})$-dependent pathway. NF- $\kappa \mathrm{B}$ activation has been detected in airway neutrophils and macrophages as well as in tracheobronchial secretions from infants with RDS [60, 61]. Increased protein levels and high mRNA expression of proinflamma- 
tory cytokines have been identified in airway secretions, bronchoalveolar and pulmonary cells and, moreover, in the systemic circulation of infants with evolving BPD by numerous investigators $[1,5,8,62]$. A transient overexpression of IL-1 in rat lungs by adenoviral gene transfer was accompanied by a local increase in TNF- $\alpha$ and IL- 6 expression and a vigorous acute inflammatory reaction with profound tissue injury and fibrotic changes [63]. Most recently, perinatal expression of IL-1 $\beta$ in pulmonary epithelial cells of a bitransgenic mouse model was shown to induce a lung disease which was clinically and histologically similar to BPD [64].

The influx of TNF- $\alpha$-positive macrophages in pulmonary tissue of preterm infants who had died of severe RDS was found to be associated with a loss of endothelial basement membrane and a destruction of interstitial glycosaminoglycans [65]. Proinflammatory cytokines do not cross the placenta [66]. There is convincing experimental and clinical data which indicate that the profound proinflammatory cytokine response present in the airways and pulmonary tissue of preterm infants may reflect an inability to regulate inflammation through an adequate expression of the anti-inflammatory cytokines IL-4, IL-10, IL-11, IL-12, IL-13, IL-18 or IL-1 receptor antagonist $[1,5,67-69]$. Cellular IL-10 mRNA was undetectable in most airway samples of preterm infants with $\mathrm{BPD}$, but it was expressed in all term infants with respiratory failure [67]. In general, monocytes of newborns seem to produce IL-10 far below the level needed to inhibit a submaximal release of IL-8 from mononuclear cells [70]. Interestingly, lung inflammatory cells of preterm infants exposed to IL-10 in vitro responded with a reduced expression of proinflammatory cytokines [71]. An imbalance between proinflammatory and anti-inflammatory cytokines, favoring the former, can be considered as an important feature of lung injury. In infants exposed to chorioamnionitis, insufficient inhibition of high fetal proinflammatory cytokine response shortly after birth may increase the risk of BPD [62].

\section{Oxidative and Proteolytic Damage}

High inspiratory oxygen concentrations can induce direct oxidative cell damage through increased production of reactive oxygen species which are released by neutrophils and macrophages at sites of inflammation. In addition, reactive oxygen species are generated under hyperoxic conditions, during reoxygenation injury by the cellbound xanthine oxidase system and in the presence of free iron $[35,72]$. Free iron was detected in the vast majority of ventilated preterm infants with RDS [72]. Oxygen rad- icals exert direct toxic effects on bronchoalveolar structures by induction of inflammation, lipid peroxidation, oxidative inactivation of protective antiproteases and upregulation of metalloproteinases [35, 72]. Animal experiments indicate that oxidative stress is a very early and crucial event in the initiation of pulmonary inflammation [73], and the activity of antioxidant enzymes such as superoxide dismutase, catalase and glutathione peroxidase may not be sufficient to combat oxidative injury [35]. Very immature preterm infants are particularly susceptible to hyperoxia and oxygen radicals since the activity of the antioxidant system is much lower compared to term newborns and the system has yet to mature. As a consequence, very immature preterm infants have a profound deficiency in antioxidant enzyme activity at the time when they are receiving high inspiratory oxygen concentrations and are most likely to be exposed to hyperoxemia [35].

At sites of inflammation neutrophils and macrophages release various potent proteases which play an essential role in the destruction of the alveolar-capillary unit and the extracellular matrix (fig. 1). These include elastase, $\beta$-glucuronidase, myeloperoxidase, cathepsin, metalloproteinase and others. There is an imbalance between elastase, a powerful neutral protease, and $\alpha_{1}$-proteinase inhibitor within the airway of preterm infants with RDS and BPD [44, 74]. $\alpha_{1}$-Proteinase inhibitor is presumably functionally inactivated by oxygen intermediates. Various markers of tissue destruction probably caused by free elastase have been identified in airway secretions and urine of preterm infants and, moreover, alveolar septation was markedly reduced in lungs of infants with increased elastase expression [3]. In addition, an imbalance between cysteine proteases and their inhibitors has recently been described [75]. Similarly, high concentrations of different matrix metalloproteinases that are involved in remodeling throughout all stages of lung development have been identified in airway secretions of infants with BPD and when overexpressed might cause disruption of the extracellular matrix. Protective levels of tissue inhibitors of metalloproteinases were rather low in these infants, also suggesting an imbalance within the metalloproteinase system $[76,77]$. Blocking matrix metalloproteinase-9 (MMP-9) activity has recently been shown to reduce oxidative injury-mediated lung damage in mice [78]. In contrast, a deficiency of MMP-9 in transgenic mice increased pulmonary cell death suggesting that MMP-9 activity in the inflamed lung has a protective role against tissue injury [79]. Elastase and other neutral proteases were shown to prime macrophages for an increased release of toxic oxygen metabolites [80]. 


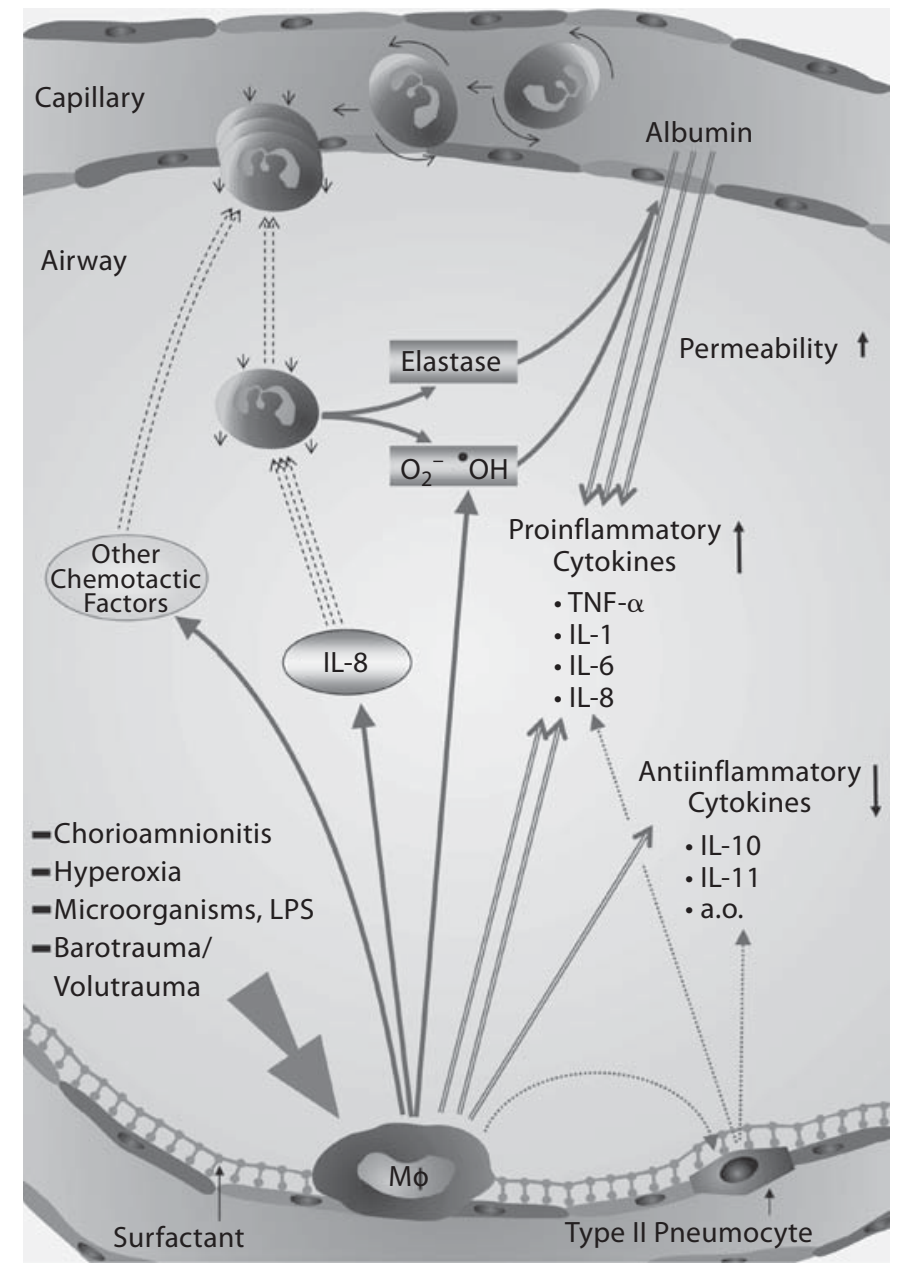

Fig. 1. Schematic representation of pulmonary inflammatory events in immature preterm infants at risk of BPD. Pre- and postnatal risk factors induce the generation and secretion of proinflammatory cytokines by alveolar macrophages and other cells. These proinflammatory mediators which have chemotactic and chemokinetic properties are responsible, in part, for the upregulation of endothelial and cellular adhesion molecules and for the recruitment and influx of neutrophils (PMN) and monocytes into the airways. Various inflammatory mediators such as free elastase, oxygen radicals $\left(\mathrm{O}_{2}^{-}, \cdot \mathrm{OH}\right)$ and proinflammatory cytokines induce an increased alveolar-capillary permeability. As a consequence, plasma proteins such as albumin entering the airways contribute to edema formation, the inactivation of the surfactant system and deterioration of lung function. An imbalance between pro- and anti-inflammatory mediators seems to favor proinflammatory mechanisms.

\section{Increased Alveolar Capillary Permeability}

An increased alveolar-capillary permeability is pathognomonic for the early and later stages of inflammation and it is clearly associated with a deterioration of lung function $[1,5]$. Numerous inflammatory mediators and cells have detrimental effects on the microvascular integrity, among them a variety of lipid mediators including leukotrienes, prostacyclin, platelet-derived factor and endothelin-1. Protein leakage into the alveoli and airways of preterm infants takes place within $1 \mathrm{~h}$ after initiation of mechanical ventilation $[51,81]$. At a postnatal age of 10-14 days, preterm infants who later developed BPD had a large increase of albumin concentrations in their airway secretions; albumin and other serum proteins profoundly contribute to alveolar edema, to the inactivation of the surfactant system and a deterioration of lung function [44, 82]. Magnetic resonance imaging in infants with BPD showed an increased lung water content and a gravity-induced collapse of the lung [83]. In mechanically ventilated infants with RDS, a simultaneous activation of clotting, fibrinolysis, kinin-kallikrein and the complement system has been observed [1]. These findings indicate that injury to the pulmonary vascular endothelium may subsequently promote neutrophil and platelet activation, and may induce pulmonary as well as systemic inflammation and activation of the clotting system [84].

\section{Repair Mechanisms and Growth Factors}

Lung injury and the associated inflammatory process lead to an induction of TGF- $\beta$ that limits some of the inflammatory reactions and plays a key role in mediating tissue remodeling and repair [85]. However, if reparative processes are exaggerated, as indicated by increased expression of TGF- $\beta$ in the lungs of preterm animals and in preterm infants with BPD, normal lung development may be inhibited and fibrosis may ensue [1, 86-89]. Recently, a reduced expression of connective tissue growth factor, which is responsible for various downstream actions of TGF- $\beta$ and which is a second important key mediator in the induction of pulmonary fibrosis, has been found in a sheep model [90]. Overexpression of TGF- $\beta$ and subsequent downregulation of connective tissue growth factor together with suboptimal levels of various growth factors may partially explain the pathogenesis of the 'new BPD' which is characterized by growth arrest of lung tissue and pulmonary vessels rather than by fibrosis. Low concentrations of hypoxic-inducible factor, keratinocyte, hepatocyte growth factors, angiopoietin and endostatin, which participate in normal lung and vascular development as well as tissue regeneration after lung injury have been detected in infants with BPD [91-96]. Similarly, an impaired expression of vascular endothelial growth factor and its angiogenic receptors in lungs from extremely preterm animals developing BPD were shown to contrib- 
ute to dysmorphic microvasculature and disrupted alveolarization [97]. Postnatal intratracheal administration of adenovirus-mediated vascular endothelial growth factor gene therapy improved survival and promoted lung capillary formation; moreover, the alveolar development was preserved in this rat model of irreversible lung injury [97].

\section{Conclusion}

During the past decade, it has become evident that there are multiple pre- and postnatal events which contribute, at least in part as a multiple-hit scenario, to the development of BPD in preterm infants. Chorioamnionitis, cytokine exposure in utero and a fetal inflammatory response plus various postnatal risk factors may induce a pulmonary inflammatory response that is probably associated with aberrant wound healing. As a devastating consequence, normal alveolarization as well as vascular development can be compromised with lifelong consequences for the infant. The inflammatory response is characterized by a rapid accumulation of inflammatory cells and, moreover, by an arsenal of injurious mediators that might directly affect the alveolar capillary unit and tissue integrity. Generally, an imbalance between pro- and anti-inflammatory mediators favoring proinflammatory mechanisms is a key feature in the pathogenesis of BPD. However, we have to realize that the exact pathogenetic sequence of acute and chronic inflammation is mainly hypothetical and speculative since the possible interaction between inflammatory cells and humoral mediators as well as regulatory aspects of inflammation in tissue injury and repair are largely descriptive and the molecular basis of these events has only been partially defined to date. Moreover, most of the reported findings reflect associations of in vitro experiments, animal studies and clinical observations in preterm infants with RDS and BPD rather than causal relationships. Especially in preterm babies with the burden of numerous pre- and postnatal risk factors and a considerable heterogeneity in disease severity as well as the limitations in study design, it seems impossible to define the significance of an individual risk factor in the pathogenesis of pulmonary inflammation [5]. Many studies have examined mediators at single or very few time points and may have missed the phasic nature of the inflammatory process, others may have investigated an insufficient number of mediators to draw reasonable conclusions about the interaction between proand anti-inflammatory mechanisms [41]. Nevertheless, our current understanding of the inflammatory mechanisms has opened up avenues which will allow us to get a deeper insight into the pathogenesis of inflammatory events and thus allow strategies to be developed that will help to prevent or ameliorate BPD in high-risk infants [98].

\section{References}

1 Speer CP: Inflammation and bronchopulmonary dysplasia: a continuing story. Semin Fetal Neonat Med 2006;11:354-362.

-2 Walsh MC, Szefler S, Davis J, Allen M, Van Marter L, Abman S, Blackmon L, Jobe A: Summary proceedings from the bronchopulmonary dysplasia group. Pediatrics 2006; 117:S52-S56.

-3 Bland RD: Neonatal chronic lung disease in the post-surfactant era. Biol Neonate 2005; 88:181-191.

-4 Speer CP: New insights into the pathogenesis of pulmonary inflammation in preterm infants. Biol Neonate 2001;79:205-209.

-5 Speer CP: Role of inflammation in the evolution of bronchopulmonary dysplasia. Drug Discov Today Dis Mech 2006;3:409-414.

-6 Speer CP: Pulmonary inflammation and bronchopulmonary dysplasia. J Perinatol 2006;26:S57-S62.
7 Speer CP: Role of inflammation in the pathogenesis of acute and chronic neonatal lung disease; in Bancalari E (ed): The Newborn Lung: Questions and Controversies in Neonatology Series. Pulmonary Volume, ed 1. Philadelphia, Saunders, 2008, pp 166186.

8 Schmidt B, Cao L, Mackensen-Haen S, Kendziorra H, Klingel K, Speer CP: Chorioamnionitis and inflammation of the fetal lung. Am J Obstet Gynecol 2001;185:173177.

9 May M, Marx A, Seidenspinner S, Speer CP: Apoptosis and proliferation in lungs of human fetuses exposed to chorioamnionitis. Histopathology 2004;45:283-290.

10 Wirbelauer J, Schmidt B, Klingel K, Cao L, Lang F, Speer CP: Serum and glucocorticoid inducible kinase in pulmonary tissue of preterm fetuses exposed to chorioamnionitis. Neonatology 2007;93:257-262.
11 Buhimschi CS, Dulay AT, Abdel-Razeq S, Zhao G, Lee S, Hodgson EJ, Bhandari V, Buhimschi IA: Fetal inflammatory response in women with proteomic biomarkers characteristic of intra-amniotic inflammation and preterm birth. Br J Obstet Gynaecol 2009;116:257-267.

12 Cao L, Wang J, Tseu I, Luo D, Post M: Maternal exposure to endotoxin delays alveolarization during postnatal rat lung development. Am J Physiol Lung Cell Mol Physiol 2009, Epub ahead of print.

13 Romero R, Garite TJ: Twenty percent of very preterm neonates (23-32 weeks of gestation) are born with bacteremia caused by genital mycoplasmas. Am J Obstet Gynecol 2008; 198:1-3. 
- 14 Van Marter LJ, Dammann O, Allred EN, 26 Fleer A, Krediet TG: Innate immunity: TollLeviton A, Pagano M, Moore M, Martin C, Developmental Epidemiology Network Investigators: Chorioamnionitis, mechanical ventilation, and postnatal sepsis as modulators of chronic lung disease in preterm infants. J Pediatr 2002;140:171-176.

15 Groneck P, Götze-Speer B, Speer CP: Inflammatory bronchopulmonary response of preterm infants with microbial colonisation of the airways at birth. Arch Dis Child Fetal Neonatal Ed 1996;74:F51-F55.

$\checkmark 16$ Cordero L, Ayers LW, Davis K: Neonatal airway colonization with Gram-negative bacilli: association with severity of bronchopulmonary dysplasia. Pediatr Infect Dis J 1997; 16:18-23.

-17 Rojas MA, Gonzalez A, Bancalari E, Claure N, Poole C, Silva-Neto G: Changing trends in the epidemiology and pathogenesis of neonatal chronic lung disease. J Pediatr 1995; 126:605-610.

-18 Bancalari E, Claure N, Gonzalez A: Patent ductus arteriosus and respiratory outcome in premature infants. Biol Neonate 2005;88: 192-201.

-19 Gonzales A, Sosenko IRS, Chandar J, Hummler H, Claure N, Bancalari E: Influence of infection on patent ductus arteriosus and chronic lung disease in premature infants weighing 1,000 grams or less. J Pediatr 1996;128:470-478.

-20 Yoder BA, Coalson JJ, Winter VT, SilerKhodr T, Duffy LB, Cassell GH: Effects of antenatal colonization with Ureaplasma urealyticum on pulmonary disease in the immature baboon. Pediatr Res 2003;54:797-807.

-21 Goldenberg RL, Andrews WW, Goepfert AR, Faye-Petersen O, Cliver SP, Carlo WA, Hauth JC: The Alabama Preterm Birth Study: umbilical cord blood Ureaplasma urealyticum and Mycoplasma hominis cultures in very preterm newborn infants. Am J Obstet Gynecol 2008;198:43.e1-43.e5.

22 Viscardi RM, Atamas SP, Luzina IG, Hasday JD, He JR, Sime PJ, Coalson JJ, Yoder BA: Antenatal Ureaplasma urealyticum respiratory tract infection stimulates proinflammatory, profibrotic responses in the preterm baboon lung. Pediatr Res 2006;60:141-146.

-23 Groneck P, Schmale J, Soditt V, Stützer H, Götze-Speer B, Speer CP: Bronchoalveolar inflammation following airway infection in preterm infants with chronic lung disease. Pediatr Pulmonol 2001;31:331-338.

-24 Kotecha S, Hodge R, Schaber JA, Miralles R, Silverman M, Grant WD: Pulmonary Ureaplasma urealyticum is associated with the development of acute lung inflammation and chronic lung disease in preterm infants. Pediatr Res 2004;55:61-68.

-25 Schelonka RL, Katz B, Waites KB, Benjamin DK Jr: Critical appraisal of the role of Ureaplasma in the development of bronchopulmonary dysplasia with metaanalytic techniques. Pediatr Infect Dis J 2005;12:10331039. like receptors and some more. A brief history, basic organization and relevance for the human newborn. Neonatology 2007;92:145-157.

27 Muscedere JG, Mullen JBM, Gan K, Slutsky AS: Tidal ventilation at low airway pressures can augment lung injury. Am J Respir Crit Care Med 1994;149:1327-1334.

28 Dreyfuss D, Saumon G: Ventilator-induced lung injury: lessons from experimental studies. Am J Respir Crit Care Med 1998;157: 294-323.

29 Albertine KH, Jones GP, Starcher BC, Bohnsack JF, Davis PL, Cho SC, Carlton DP, Bland RD: Chronic lung injury in preterm lambs. Disordered respiratory tract development. Am J Respir Crit Care Med 1999;159:945958.

30 Tremblay L, Valenza F, Ribeiro SP, Li J, Slutsky AS: Injurious ventilatory strategies increase cytokines and c-fos m-RNA expression in an isolated rat lung model. J Clin Invest 1997;99:944-952.

31 Thome U, Goetze-Speer B, Speer CP, Pohlandt F: Comparison of pulmonary inflammatory mediators in preterm infants treated with intermittent positive pressure ventilation or high frequency oscillatory ventilation. Pediatr Res 1998;44:330-337.

32 May M, Ströbel P, Preisshofen T, Seidenspinner S, Marx A, Speer CP: Apoptosis and proliferation in lungs of stillborn fetuses and ventilated preterm infants with respiratory distress syndrome. Eur Respir J 2004;23:113-121.

33 Copland IB, Martinez F, Kavanagh BP, Engelberts D, McKerlie C, Belik J, Post M: High tidal volume ventilation causes different inflammatory responses in newborn versus adult lung. Am J Respir Crit Care Med 2004; 169:739-748.

34 Ricard JD, Dreyfuss D, Saumon G: Production of inflammatory cytokines in ventilator-induced lung injury: a reappraisal. Am J Respir Crit Care Med 2001;163:1176-1180.

35 Saugstad OD: Oxidative stress in the newborn - a 30-year perspective. Biol Neonate 2005;88:228-236.

-36 Saugstad OD: Bronchopulmonary dysplasia and oxidative stress: Are we closer to an understanding of the pathogenesis of BPD? Acta Paediatr 1997;86:1277-1282.

37 Coalson JJ: Experimental models of bronchopulmonary dysplasia. Biol Neonate 1997; 71:35-38.

38 Bonikos DS, Bensch KG, Ludwin SK, Northway WH Jr: Oxygen toxicity in the newborn: the effect of prolonged $100 \% \mathrm{O}_{2}$ exposure on the lungs of newborn mice. Lab Invest 1975; 32:619-635

39 Wagenaar GT, ter Horst SA, van Gastelen MA, Leijser LM, Mauad T, van der Velden PA, de Heer E, Hiemstra PS, Poorthuis BJ, Walther FJ: Gene expression profile and histopathology of experimental bronchopulmonary dysplasia induced by prolonged oxidative stress. Free Radic Biol Med 2004;36: 782-801.
40 Vuichard D, Ganter MT, Schimmer RC, Suter D, Booy C, Reyes L, Pasch T, BeckSchimmer B: Hypoxia aggravates lipopolysaccharide-induced lung injury. Clin Exp Immunol 2005;141:248-260.

-41 Bose CL, Dammann CEL, Laughon MM: Bronchopulmonary dysplasia and inflammatory biomarkers in the premature neonate. Arch Dis Child Fetal Neonatal Ed 2008; 93:F455-F461.

42 Lin HC, Su BH, Chang JS, Hsu CM, Tsai CH, Tsai FJ: Nonassociation of interleukin-4 intron 3 and 590 promoter polymorphisms with bronchopulmonary dysplasia for ventilated preterm infants. Biol Neonate 2005;87: 181-186.

-43 Kwinta P, Bik-Multanowski M, Mitkowska Z, Tomasik T, Legutko M, Pietrzyk JJ: Genetic risk factors of bronchopulmonary dysplasia. Pediatr Res 2008;64:682-688.

44 Groneck P, Goetze-Speer B, Oppermann M, Eiffert H, Speer CP: Association of pulmonary inflammation and increased microvascular permeability during the development of bronchopulmonary dysplasia: a sequential analysis of inflammatory mediators in respiratory fluids of high risk preterm infants. Pediatrics 1994;93:712-718.

$\checkmark 4$ Merritt TA, Cochrane CG, Holcomb K, Bohl B, Hallman M, Strayer D, Edwards DK 3rd, Gluck L: Elastase and $\alpha_{1}$-proteinase inhibitor activity in tracheal aspirates during respiratory distress syndrome. J Clin Invest 1983;72:656-666.

46 Ogden BE, Murphy SA, Saunders GC, Pathak D, Johnson JD: Neonatal lung neutrophils and elastase/proteinase inhibitor imbalance. Am Rev Respir Dis 1984;130:817-821.

$\checkmark 47$ Arnon S, Grigg J, Silverman M: Pulmonary inflammatory cells in ventilated preterm infants: effect of surfactant treatment. Arch Dis Child 1993;69:44-48.

48 Kotecha S, Chan B, Azam N, Silverman M, Shaw RJ: Increase in interleukin- 8 and soluble intercellular adhesion molecule-1 in bronchoalveolar lavage of premature infants with chronic lung disease. Arch Dis Child 1995;72:F90-F96.

49 Ferreira PJ, Bunch TJ, Albertine KH, Carlton DP: Circulating neutrophil concentration and respiratory distress in premature infants. J Pediatr 2000;136:466-472.

50 Carlton DP, Albertine KH, Cho SC, Lont M, Bland RD: Role of neutrophils in lung vascular injury and edema after premature birth in lambs. J Appl Physiol 1997;83:1307-1317.

51 Jaarsma A, Braaksma MA, Geven WB, van Oeveren W, Oetomo SB: Activation of the inflammatory reaction within minutes after birth in ventilated preterm lambs with neonatal respiratory distress syndrome. Biol Neonate $2004 ; 86: 1-5$

52 Palta M, Sadek-Badawi M, Carlton DP: Association of BPD and IVH with early neutrophil and white counts in VLBW neonates with gestational age $<32$ weeks. J Perinatol 2008;28:604-610. 
-53 Turunen R, Nupponen I, Siitonen S, Repo H, Andersson S: Onset of mechanical ventilation is associated with rapid activation of circulating phagocytes in preterm infants. Pediatrics 2006;117:448-454.

54 Murch SH, Costeloe K, Klein NJ, MacDonald TT: Early production of macrophage inflammatory protein- $1 \alpha$ occurs in respiratory distress syndrome and is associated with poor outcome. Pediatr Res 1996;40:490-497.

55 Hanna N, Vasquez P, Pham P, Heck DE, Laskin JD, Laskin DL, Weinberger B: Mechanisms underlying reduced apoptosis in neonatal neutrophils. Pediatr Res 2005;57: $56-62$.

56 Yi M, Jankov RP, Belcastro R, Humes D, Copland I, Shek S, Sweezey NB, Post M, Albertine $\mathrm{KH}$, Auten RL, Tanswell AK: Opposing effect of $60 \%$ oxygen and neutrophil influx on alveologenesis in the neonatal rat. Am J Respir Crit Care Med 2004;170:11881196.

-57 De Visser YP, Walther FJ, Laghmani EH, van Wijngaarden S, Nieuwland K, Wagenaar GT: Phosphodiesterase 4 inhibition attenuates pulmonary inflammation in neonatal lung injury. Eur Respir J 2008;31:633-644.

58 Woyda K, Koebrich S, Reiss I, Rudloff S, Pullamsetti SS, Rühlmann A, Weissmann N, Ghofrani HA, Günther A, Seeger W, Grimminger F, Morty RE, Schermuly RT: Inhibition of phosphodiesterase 4 enhances lung alveolarisation in neonatal mice exposed to hyperoxia. Eur Respir J 2009;33:861-870.

-59 D’Alquen D, Kramer BW, Seidenspinner S, Marx A, Berg D, Groneck P, Speer CP: Activation of umbilical cord endothelial cells and fetal inflammatory response in preterm infants with chorioamnionitis and funisitis. Pediatr Res 2005;57:263-269.

-60 Cao L, Liu C, Cai B, Jia X, Kang L, Speer CP, Sun B: Nuclear factor- $\kappa \mathrm{B}$ expression in alveolar macrophages of mechanically ventilated neonates with respiratory distress syndrome. Biol Neonate 2004;86:116-123.

61 Cheah FC, Winterbourn CC, Darlow BA, Mocatta TJ, Vissers MC: Nuclear factor- $\kappa B$ activation in pulmonary leukocytes from infants with hyaline membrane disease: associations with chorioamnionitis and Ureaplasma urealyticum colonization. Pediatr Res 2005;57:616-623.

-62 Paananen R, Husa A-K, Vuolteenaho R, Herva $R$, Kaukola T, Hallman M: Blood cytokines during the perinatal period in very preterm infants: relationship of inflammatory response and bronchopulmonary dysplasia. J Pediatr 2009;154:39-43.

63 Kolb M, Margetts PJ, Anthony DC, Pitossi F, Gauldie J: Transient expression of IL-1 $\beta$ induces acute lung injury and chronic repair leading to pulmonary fibrosis. J Clin Invest 2001;107:1529-1536.
64 Bry K, Whitsett JA, Lappalainen U: IL-1 $\beta$ disrupts postnatal lung morphogenesis in the mouse. Am J Respir Cell Mol Biol 2007; 36:32-42.

65 Murch SH, Costeloe K, Klein NJ, Rees H, McIntosh N, Keeling JW, MacDonald TT: Mucosal tumor necrosis factor- $\alpha$ production and extensive disruption of sulfated glycosaminglycans begin within hours of birth in neonatal respiratory distress syndrome. Pediatr Res 1996;40:484-489.

66 Aaltonen R, Heikkinen T, Hakala K, Laine K, Alanen A: Transfer of proinflammatory cytokines across term placenta. Obstet Gynecol 2005; 106:802-807.

67 Jones CA, Cayabyab RG, Kwong KY, Stotts C, Wong B, Hamdan $\mathrm{H}$, Minoo P, deLemos RA: Undetectable interleukin (IL)-10 and persistent IL-8 expression early in hyaline membrane disease: a possible developmental basis for the predisposition to chronic lung inflammation in preterm newborns. Pediatr Res 1996;39:966-975.

68 Kakkera DK, Siddiq MM, Parton LA: Interleukin-1 balance in the lungs of preterm infants who develop bronchopulmonary dysplasia. Biol Neonate 2004;87:82-90.

69 Chetty A, Cao GJ, Manzo N, Nielsen HC, Waxman A: The role of IL- 6 and IL-11 in hyperoxic injury in developing lung. Pediatr Pulmonol 2008;43:297-304.

70 Davidson D, Miskolci V, Clark DC, Dolmaian G, Vancurova I: Interleukin-10 production after pro-inflammatory stimulation of neutrophils and monocytic cells of the newborn. Comparison to exogenous interleukin-10 and dexamethasone levels needed to inhibit chemokine release. Neonatology 2007;92:127-133.

71 Kwong KYC, Jones CA, Cayabyab R, Lecart C, Khuu N, Rhandhawa I, Hanley JM, Ramanathan R, deLemos RA, Minoo P: The effects of IL-10 on proinflammatory cytokine expression (IL-1 $\beta$ and IL-8) in hyaline membrane disease. Clin Immunol Immunopathol 1998;88:105-113.

72 Gerber CE, Bruchelt G, Stegmann H, Schweinsberg F, Speer CP: Presence of bleomycin-detectable free iron in the alveolar system of preterm infants. Biochem Biophys Res Commun 1999;257:218-222.

73 Kramer BW, Kramer S, Ikegami M, Jobe AH Injury inflammation and remodelling in fetal sheep lung after intraamniotic endotoxin. Am J Physiol 2002;283:L452-L459.

74 Speer CP, Ruess D, Harms K, Herting E, Gefeller O: Neutrophil elastase and acute pulmonary damage in neonates with severe respiratory distress syndrome. Pediatrics 1993; 91:794-799.

75 Altiok O, Ysumatsu R, Bingol-Karakoc G: Imbalance between cysteine proteases and inhibitors in a baboon model of bronchopulmonary dysplasia. Am J Respir Crit Care Med 2006;173:318-326.
76 Schock BC, Sweet DG, Ennis M, Warner JA, Young IS, Halliday HL: Oxidative stress and increased type-IV collagenase levels in bronchoalveolar lavage fluid from newborn babies. Pediatr Res 2001;50:29-33.

77 Cederquist K, Sorsa T, Tervahartiala T, Maisi P, Reunanen K, Lassus P, Andersson S: Matrix metalloproteinases-2, -8 , and -9 and TIMP-2 in tracheal aspirates from preterm infants with respiratory distress. Pediatrics 2001;108:686-692.

78 Chetty A, Cao GJ, Severgnini M, Simon A, Warburton R, Nielsen HC: Role of matrix metalloprotease-9 (MMP-9) in hyperoxic injury in developing lung. Am J Physiol 2008; 29:L584-L592.

79 Lukkarinen H, Hogmalm A, Lappalainen U, Bry K: Matrix metalloproteinase-9 deficiency worsens lung injury in a model of bronchopulmonary dysplasia. Am J Respir Cell Mol Biol 2009 (in press).

80 Speer CP, Pabst M, Hedegaard HB, Rest RF, Johnston RB: Enhanced release of oxygen metabolites by monocyte-derived macrophages exposed to proteolytic enzymes: activity of neutrophil elastase and cathepsin G. J Immunol 1984;133:2151-2156.

-81 Jaarsma AS, Braaksma MA, Geven WB, van Oeveren W, Oetomo SB: Early activation of inflammation and clotting in the preterm lamb with neonatal RDS: comparison of conventional ventilation and high frequency oscillatory ventilation. Pediatr Res 2001;50: 650-657.

82 Wirbelauer J, Speer CP: The role of surfactant treatment in preterm infants and term newborn with acute respiratory distress syndrome. J Perinatol 2009 (in press).

83 Adams EW, Harrison MC, Counsell SJ, Allsop JM, Kennea NL, Hajnal JV, Thornton AS, Duggan P, Edwards AD: Increased lung water and tissue damage in bronchopulmonary dysplasia. J Pediatr 2004;145:503-507.

- 84 Sitaru AG, Holzhauer S, Singer D, Obergfell A, Walter U, Speer CP: Neonatal platelets from cord blood and peripheral blood. Platelets 2005;16:203-210.

85 Bartram U, Speer CP: The role of transforming growth factor- $\beta$ in lung development and disease. Chest 2004;125:754-765.

86 Kotecha S, Wangoo A, Silverman M, Shaw RJ: Increase in the concentration of transforming growth factor- $\beta_{1}$ in bronchoalveolar lavage fluid before the development of chronic lung disease of prematurity. J Pediatr 1996; 128:464-469.

-87 Lecart C, Cayabyab R, Buckley S, Morrison J, Kwong KY, Warburton D, Ramanathan R, Jones CA, Minoo P: Bioactive transforming growth factor- $\beta$ in the lungs of extremely low birth weight neonates predicts the need for home oxygen supplementation. Biol Neonate $2000 ; 77: 217-223$. 
88 Jónsson B, Li Y-H, Noack G, Brauner A, Tullus K: Downregulatory cytokines in tracheobronchial aspirate fluid from infants with chronic lung disease of prematurity. Acta Paediatr 2000;89:1375-1380.

89 Ichiba H, Saito M, Yamano T: Amniotic fluid transforming growth factor- $\beta_{1}$ and the risk for the development of neonatal bronchopulmonary dysplasia. Neonatology 2009;96: 156-161.

90 Kunzmann S, Seher A, Kramer BW, Schenk R, Schutze N, Jakob F, Sebald W, Speer CP: Connective tissue growth factor does not affect transforming growth factor- $\beta_{1}$-induced Smad3 phosphorylation and T-lymphocyte proliferation. Int Arch Allergy Immunol 2008;147:152-160.

-91 Danan C, Franco ML, Jarreau PH, Dassieu G, Chailley-Heu B, Bourbon J, Delacourt C: High concentrations of keratinocyte growth factor in airways of premature infants predicted absence of bronchopulmonary dysplasia. Am J Respir Crit Care Med 2002;165: 1384-1367.
92 Lassus P, Heikkila P, Andersson LC, von Boguslawski K, Andersson S: Lower concentration of pulmonary hepatocyte growth factor is associated with more severe lung disease in preterm infants. J Pediatr 2003;143:199202.

93 Asikainen TM, Ahmad A, Schneider BK, White CW: Effect of preterm birth on hypoxia-inducible factors and vascular endothelial growth factor in primate lungs. Pediatr Pulmonol 2005;40:538-546.

94 Thomas W, Seidenspinner S, KawczynskaLeda N, Kramer BW, Chmielnicka-Kopaczyk M, Marx A, Szymankiewicz M, Speer CP: Systemic fetal inflammation and reduced concentrations of macrophage migration inhibitory factor in airways of extremely premature infants. Am J Obstet Gynecol 2008;64:e1-e4.

95 Thomas W, Seidenspinner S, Kramer BW, Kawczyńska-Leda N, Chmielnicka-Kopaczyk M, Marx A, Wirbelauer J, Szymankiewicz M, Speer CP: Airway concentrations of angiopoietin-1 and endostatin in ventilated extremely premature infants are decreased after funisitis and unbalanced with bronchopulmonary dysplasia/death. Pediatr Res 2009;65:468-473.
96 Ohki Y, Mayuzumi H, Tokuyama K, Yoshizawa Y, Arakawa H, Mochizuki H, Morikawa A: Hepatocyte growth factor treatment improves alveolarization in a newborn murine model of bronchopulmonary dysplasia. Neonatology 2008;95:332-338.

97 Thébaud B, Ladha F, Michelakis ED, Sawicka M, Thurston G, Eaton F, Hashimoto K, Harry G, Haromy A, Korbutt G, Archer SL: Vascular endothelial growth factor gene therapy increases survival, promotes lung angiogenesis, and prevents alveolar damage in hyperoxia-induced lung injury: evidence that angiogenesis participates in alveolarization. Circulation 2005;112:2477-2486.

98 Thomas W, Speer CP: Nonventilatory strategies for prevention and treatment of bronchopulmonary dysplasia - what is the evidence? Neonatology 2008;94:150-159. 